\title{
Advanced removal of trichloroethylene from water by sonolysis, biocatalytic oxidation and ultrafiltration
}

https://doi.org/10.21698/rjeec.2020.105

Original research

\section{MIHAI STEFANESCU, IONUT CRISTEA, GHEORGHE BATRINESCU}

National Research and Development Institute for Industrial Ecology - ECOIND, 71-73 Drumul Podu Dambovitei, 060652, Bucharest, mihai.stefanescu@incdecoind.ro, Romania

\begin{abstract}
Trichloroethylene (TCE) causes important pollution problems of soil and groundwater in other countries even in this day when its direct application is less than the last century.

This paper emphasized a modern treatment flow for trichloroethylene advanced removal from water based on four phases: sonolysis - biocatalytical oxidation - sonolysis - ultrafiltration. Following this scheme, it is possible to obtain residual TCE content in the effluent approx. $0.01 \mathrm{mg} / \mathrm{L}$, from initial content of $0.5 \mathrm{mg}$ TCE/L. Ultrasonic energy (50-200 kJ) biocatalyst dose (laccase), biocatalytic oxidation time and ultrafiltration separation capacity are the main operating parameters which control the TCE removal efficiency (max. 87\%).
\end{abstract}

Keywords: trichloroethylene, laccase, sonolysis, biocatalyst, ultrafiltration

\section{INTRODUCTION}

Trichloroethylene (TCE) is a toxic and carcinogenic compound which is constant detected in atmosphere, soil and underground water in many regions of the world because of inadequate disposal method in many countries [1].

This aliphatic organochlorinated compound is heavier than water and can penetrate the soil until groundwater level where could generate pollution plumes and contamination of groundwater for a long time in that area and beyond [2].

It is well known that TCE is hard to be oxidize even with advanced oxidation processes (AOPs) based on hydroxyl radicals (e.g. Fenton oxidation) [3]. Ultrasonic field degrades TCE not only because of hydroxyl radical generation during the water sonolysis but also because the high levels of temperature and pressure inside the microbubbles generated by ultrasonic cavitation effect [4].

There are many possibilities to combine sonolysis with other advanced oxidation methods in order to assure a higher level of micropollutants mineralization as US + UV, US $+\mathrm{O}_{3}$, US $+\mathrm{H}_{2} \mathrm{O}_{2}+\mathrm{UV}$ a.s.o. with increasing of operational costs. Biological degradation could be an option in same specific polluted waters [5].

TCE can be removed from water biologically which is a classical method in case of biological treatment of wastewater treatment plants [6]. Only few studies indicate the possibility to use biological processes, including biocatalyse, to remove organochlorinated compounds from drinking water $[7,8]$.

Membrane processes like nanofiltration and reverse osmosis have good results in order to remove organic or inorganic compounds from drinking water the main disadvantage being the transfer of the pollutant from drinking water in other more concentrated solution which must be treated/processed at the end $[9,10]$.

Physical-chemical and biological treatment processes can be combined in the same treatment flow in order to have the best removal efficiencies of micropollutants.

This is the aim of the following experimental test, to prove that TCE can be successfully remove by sonolysis, biocatalyse and ultrafiltration combined methods. 


\section{EXPERIMENTAL PART}

The influence of ultrasonic energy, the biocatalyst doses and reaction $\mathrm{pH}$ were the main parameters of the experimental treatment flow. Ultrafiltration final treatment step was introduced in order to recover the biocatalyst. Ultrasonication of aqueous solution with TCE content was performed in an ultrasonic SONICS Vibra Cell reactor having water cooling jacket (fig.1).

The main experimental conditions were as following:

- ultrasonic frequency, constant: $20 \mathrm{kHz}$;

- ultrasonic energy: $50 \mathrm{~kJ}$ for the first sonolysis step and $200 \mathrm{~kJ}$ for the second one (optimal treatment);

- sonolysis time: 5 - $20 \mathrm{~min}$;
- initial TCE concentration, constant: 0.5 $\mathrm{mg} / \mathrm{L}$;

- pH reaction domain: $2.2 \div 10.9$

- biocatalyst: laccase Trametes versicolor, $1.07 \mathrm{U} / \mathrm{mg}$;

- biocatalyst - aqueous solution contact: orbital shaker, $150 \mathrm{rpm}$;

- laccase dose: $0.066 ; 0.133 ; 0.333 ; 0.533$; $1.333 ; 1.999 \mathrm{~g} / \mathrm{L}$;

- biocatalytic oxidation time, constant: 2 hours.;

- blank samples (water + TCE) without ultrasonic and biological treatment steps, just aeration on orbital shaker

- biocatalyst separation with an ultrafiltration cellulosic HYDROSART (Sartorius) membrane, $30 \mathrm{kDa}$.

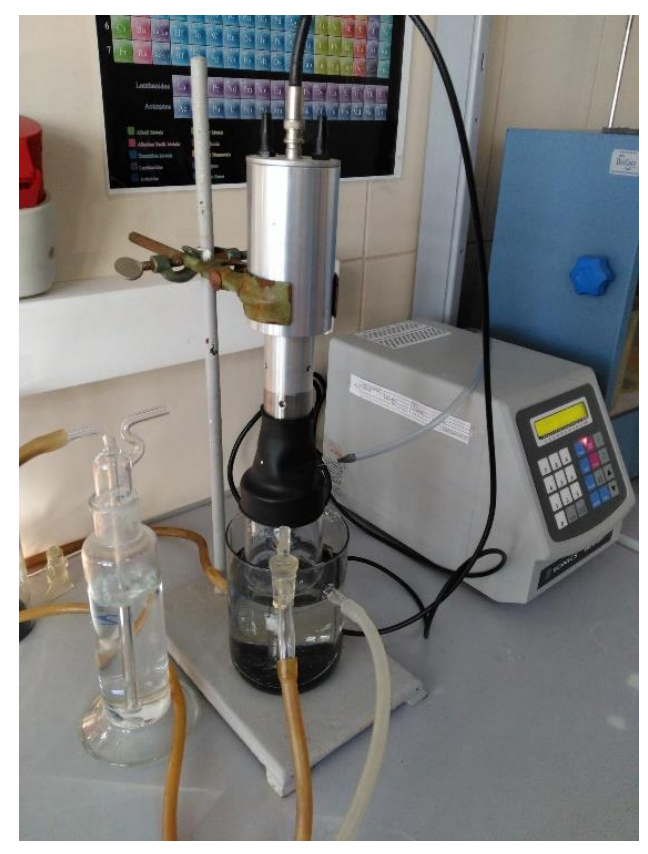

Fig. 1. Ultrasonic reactor

The treatment scheme flow of TCE advanced removal from aqueous solution is shown in figure 2 . 


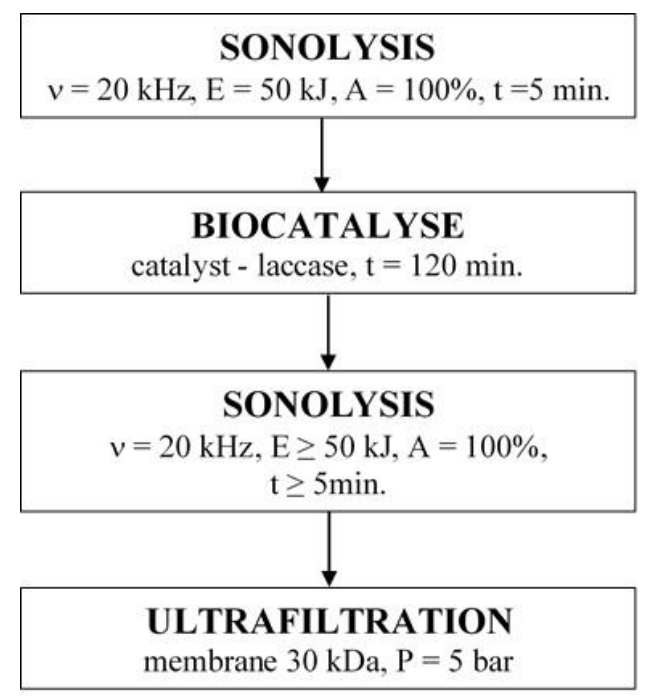

Fig. 2. TCE removal treatment flow

\section{RESULTS AND DISCUSSION}

The influence of reaction $\mathrm{pH}$, laccase dose and ultrasonic energy were investigated. The other experimental parameters were established in the frame of preliminary experimental studies.

\section{The influence of reaction $\mathrm{pH}$}

The effect of $\mathrm{pH}$ on TCE removal efficiency was of $0.074 \mathrm{mg} / \mathrm{L}$ (sample P5 at $\mathrm{pH} 7.5$ ) - 0.155 evaluated for $0.07 \mathrm{~g}$ laccase/L dose and $50 \mathrm{~kJ} \mathrm{mg} / \mathrm{L}$ (sample P8 at $\mathrm{pH} 11$ ). The minimal TCE sonolysis energy for both ultrasonication phases. residual content was still over the limit $(0.01 \mathrm{mg}$ The residual TCE concentrations (table 1) in the TCE/L) for the influent of drinking water effluent of the treatment flow, were in the range treatment plants.

Table 1. The influence of reaction $\mathrm{pH}$ on TCE residual content

\begin{tabular}{c|ccc}
\hline Sample & $\begin{array}{c}\mathrm{pH} \\
\text { initial }\end{array}$ & $\begin{array}{c}\mathrm{pH} \\
\text { effluent }\end{array}$ & $\begin{array}{c}\text { Residual TCE } \\
\text { concentrations, } \\
\mathrm{mg} / \mathrm{L}\end{array}$ \\
\hline P1 & 2.22 & 2.03 & 0.128 \\
P2 & 3.12 & 2.91 & 0.134 \\
P3 & 4.16 & 4.35 & 0.126 \\
P4 & 5.3 & 5.55 & 0.118 \\
P5 & 7.50 & 6.71 & 0.074 \\
P6 & 9.03 & 7.52 & 0.098 \\
P7 & 9.98 & 9.51 & 0.110 \\
P8 & 10.97 & 10.53 & 0.155 \\
\hline
\end{tabular}

The evolution of real TCE removal efficiencies is presented in figure 3 .

Real TCE removal efficiency means the removal capacity of the treatment proposed flow taking into account natural evaporation of TCE (blank samples).

TCE removal efficiency was between $75.5 \%$ and $86.6(\mathrm{pH}=7.5)$ 


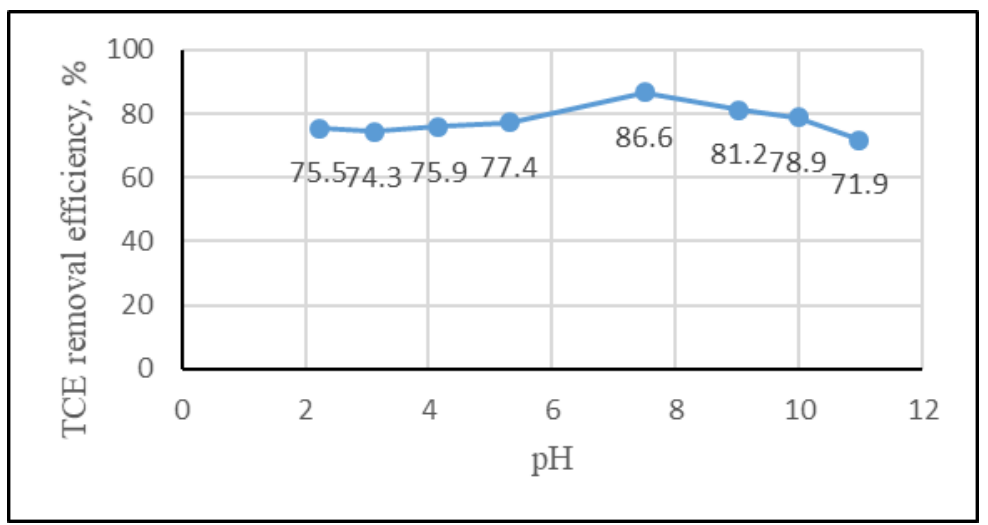

Fig. 3. TCE removal efficiency vs. reaction $\mathrm{pH}$

The influence of biocatalyst dose

The effect of laccase dose on TCE removal The residual TCE concentrations (table 2) in the efficiency was evaluated for $\mathrm{pH}=7,7$ and $50 \mathrm{~kJ}$ effluent of treatment flow, were in the range of ultrasonic energy for both sonolysis steps. The $0.10 \mathrm{mg} / \mathrm{L}$ (sample L4) - $0.15 \mathrm{mg} / \mathrm{L}$ (sample laccase doses were $0.133 ; 0.333 ; 0.533 ; 1.333$ L3). $\mathrm{g} / \mathrm{L}$.

Table 1. The influence of reaction $\mathrm{pH}$ on TCE residual content

\begin{tabular}{c|ccc}
\hline Sample & $\begin{array}{c}\mathrm{pH} \\
\text { initial }\end{array}$ & $\begin{array}{c}\text { Laccase } \\
\text { dose, } \mathrm{g} / \mathrm{L}\end{array}$ & $\begin{array}{c}\text { Residual TCE } \\
\text { concentrations, } \\
\mathrm{mg} / \mathrm{L}\end{array}$ \\
\hline L1 & & 0.133 & 0.115 \\
L2 & 7.7 & 0.333 & 0.128 \\
L3 & & 0.533 & 0.151 \\
L4 & & 1.333 & 0.106 \\
\hline
\end{tabular}

TCE removal efficiency (figure 4) was between $82-84 \%$ (maximum in case of L4 sample with the higher dose of catalyst).

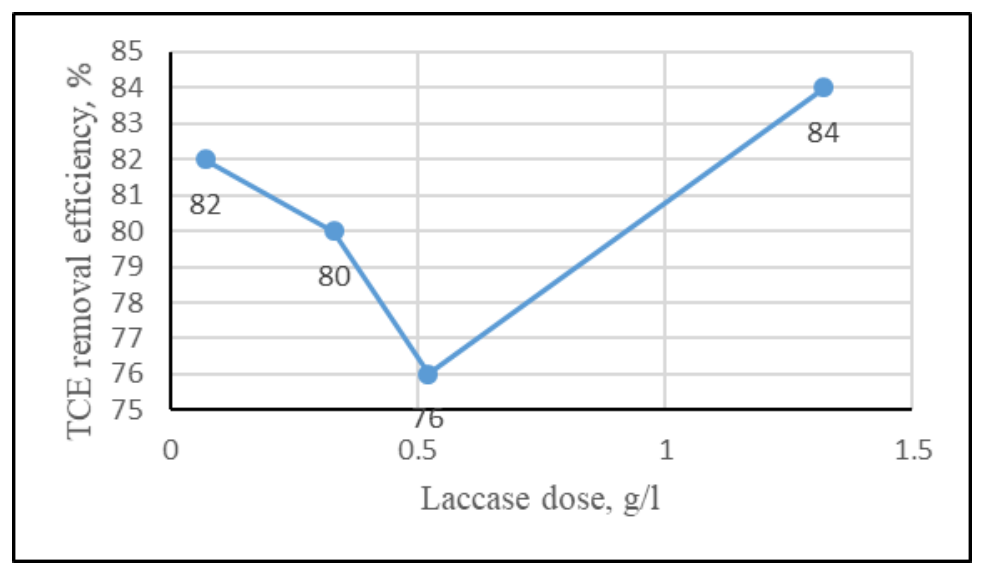

Fig. 4. TCE removal efficiency vs. laccase dose

The evolution of removal efficiencies was not real TCE degradation, which was $41 \%$ for the linear and, in the selected catalyst doses domain, higher dose of catalyst and only 18\% for the the TCE removal yields were very close. The lower one.

most important observation is referring to the The above experimental test conditions were not 
able to assure $0.01 \mathrm{mg}$ TCE/L in the effluent so, it was raised the amount of biocatalyst to $2 \mathrm{~g}$ laccase/L and the ultrasonication time for the second sonolysis step was change to 20 minutes (200 kJ energy).

\section{CONCLUSIONS}

The experimental results based on preliminary and present TCE degradation tests emphasized that the proposed treatment flow SONOLYSIS BIOCATALYTICAL OXIDATION SONOLYSIS - ULTRAFILTRATION is efficient for advanced removal of trichloroethylene from aqueous solution having initial concentration below $0.5 \mathrm{mg} / \mathrm{l}$. The lower residual TCE concentration was close to the concentration limit for drinking water treatment plant influent. The proposed treatment
In these new conditions, the residual amount of TCE was $0.011 \mathrm{mg} / \mathrm{L}$. The same amount of catalyst can be reuse for two times after ultrafiltration recovery step.

flow is flexible and it is posible to have a fine control of rezidual micropolutant by changing sonolysis energy. In the present study, $2 \mathrm{~g}$ laccase/L and maximum $200 \mathrm{~kJ}$ ultrasonic energy were optimal for TCE removal. The ultrafiltration membrane $(30 \mathrm{kDa})$ have done a good separation of the biocatalyst because the global organic load (oxidability indicator CCOMn) in the effluent was below the admited

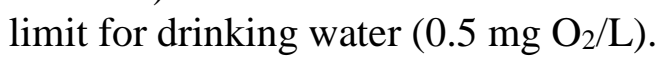

\section{ACKNOWLEDGEMENTS}

The work was funded by Ministry of Research and Innovation of Romania through Programme Nucleu, contract no. 20N/2019, Project code PN 19040301.

\section{REFERENCES}

[1] CHOWDHURY, P., VIRARAGHAVAN, [6] SAEZ, V., Ultrason. Sonochem., 18, no. 1, T., Sci. Total Environ., 407, no. 8, 2009, p. 2011, p. 104.

2474.

[2] SUTAR, R. S., RATHOD, V. K., J. Ind. Eng. Chem., 31, 2015, p. 276.

[3] GARCIA, J. G., SAEZ, V.,TUDELA I., GARCIA M.I.D., Water, 2, no. 1, 2010, p. 28.

[4] TIJANI, J. O., FATOBA, O. O., MADZIVIRE, G., PETRIK, L. F., Water Air Soil Poll., 225, no. 2122, 2014, p. 1.

[5] LIM, M. H., KIM, S. H., KIM, Y. U., https://doi.org/10.1016/j.cej.2018.04.162

[7] PANG, Y. L., ABDULLAH, A. Z., BHATIA, S., Desalination, 277, 2011, p. 1.

[8] LEE, M., OH, J., Ultrason. Sonochem., 17, no. 1,2010, p. 207.

[9] ROKHINA, E. V., LENS, P., VIRKUTYTE, J., Trends Biotechnol., 27, no. 5, 2009, p. 298.

[10] PUliCHARLA, R., Chem. Eng. J., 347, 2018, p. 828,

KHIM, J., Ultrason. Sonochem., 14, no. 2, 2007, p. 93. 